\title{
DISRUPTION AND IMPLEMENTATION OF INNOVATIVE LEARNING MODELS AND MEDIA ON READING AND WRITING JAVANESE ALPHABET IN ELEMENTARY SCHOOL
}

\author{
Joko Daryanto \\ Universitas Sebelas Maret \\ jokodaryanto@fkip.uns.ac.id
}

Article History

accepted 09/07/2018

approved 01/08/2018

published 17/09/2018

\section{Keywords}

Disrupsi, aksara Jawa, model dan media pembelajaran inovatif.

\begin{abstract}
Pembelajaran inovatif yang bersifat konstruktivisme serta mengarah pada pembelajaran yang bermakna, menjembatani interaksi guru dan peserta didik merupakan konsekuensi logis dari efek lompatan teknologi digital dan teknologi informasi yang menghasilkan akses serba cepat di era disrupsi. Aksara Jawa adalah bagian dari kebudayaan lokal yang harus dilestarikan di era disrupsi sebagai salah satu kekayaan budaya lokal yang sarat dengan nilai-nilai dan ajaran moral. Implementasi model dan media pembelajaran inovatif merupakan salah satu upaya upaya pelestarian kebudayaan lokal yang berupa aksara Jawa di ranah pendidikan dasar. Penelitian yang dilakukan di dua sekolah dasar dengan menggunakan model dan media pembelajaran inovatif menghasilkan peningkatan ketrampilan membaca dan menulis aksara Jawa. Penelitian yang dilakukan di SD Negeri 1 Boyolali pada uji pratindakan diperoleh hasil rata-rata kelas 50,75 dengan ketuntasan klasikal 12,50\%. Pada siklus I nilai rata-rata kelas meningkat menjadi 68,09 dengan ketuntasan klasikal 56,25\%, dan pada siklus II nilai rata-rata kelas meningkat menjadi 79,14 dengan ketuntasan klasikal 87,50\%. Dapat disimpulkan bahwa penggunaan media Pop Up Book dapat meningkatkan keterampilan membaca aksara Jawa pada siswa kelas IV SD Negeri 1 Boyolali. Dengan tindakan yang sama, penelitian di kelas VA SD Muhammadiyah Wonogiri mendapat nilai rata-rata 27,04 dengan ketuntasan klasikal 19,23\% pada uji pratindakan, siklus I rata-rata 68,21 dengan ketuntasan klasikal 70,83\%, siklus II nilai rata-rata 81,25 dengan ketuntasan klasikal 91,67\% sehingga didapat kesimpulan bahwa model pembelajaran make a match dapat meningkatkan ketrampilan menulis aksara Jawa siswa kelas VA SD Muhammadiyah Wonogiri. Dari dua penelitian tersebut dapat disimpulkan bahwa model dan media pembelajaran inovatif dapat meningkatkan ketrampilan membaca dan menulis aksara Jawa di era disrupsi.
\end{abstract}

Social, Humanities, and Education Studies (SHEs): Conference Series https://jurnal.uns.ac.id/shes

p-ISSN 2620-9284 e-ISSN 2620-9292 


\section{PENDAHULUAN}

Surat Keputusan Gubernur Jawa Tengah Nomor 423.5/5/2010 dan Nomor 423.5/27/2011 tentang Kurikulum Mata Pelajaran Bahasa Jawa untuk jenjang pendidikan SD/ SDLB/ MI, SMP/ SMPLB/ MTs dan SMA/ SMALB/ SMK/ MA negeri dan swasta mensyaratkan bahwa Bahasa Jawa merupakan muatan lokal wajib di Provinsi Jawa Tengah. Hal ini merupakan salah upaya pemerintah menjaga kelestarian BahasaJawa. Kelestarian Bahasa Jawa menjadi penting ketika Bahasa Jawa sebagai produk kebudayaan Jawa memiliki peran penting karena dalam Bahasa Jawa terkandung nilai-nilai luhur seperti nilai tata karma dan nilai kesopanan. Rohmadi dan Hartono (2008: 190) berpendapat bahwa Bahasa Jawa merupakan mata pelajaran yang tidak hanya untuk melestarikan budaya daerah, tetapi juga digunakan sebagai media peningkatan budi pekerti siswa yang mengalami penurunan akhlak sopan santun. Mulai dari tata cara berbicara atau biasa disebut unggah-ungguh hingga pembelajaran tentang hasil kebudayaan Jawa lainnya seperti wayang, tembang dolanan, macapat dan juga aksara Jawa dipelajari dalam mata pelajaran Bahasa Jawa sehingga perlu dijaga kelestariannya.

\section{METODE}

Berdasarkan hasil uji efektivitas yang dilakukan oleh Faninda Fitri Rahmawati menggunakan prosedur one shot case study one shot case study (Cresswel, 2016: 230) yang melibatkan satu kelas dengan pengukuran tanpa model danmedia pembelajaran dan dilanjutkan dengan pengukuran menggunakan model dan media pembelajaran inovatif dalam dua sikluspada siswa kelas IV SD Negeril Boyolali dan kelas VA SD Muhammadiyah Wonogiri.

\section{PEMBAHASAN}

Berdasarkan data dari penelitian yang dilakukan oleh Isti Khomah (2018) makadapat disimpulkan bahwa hasil keterampilan membaca aksara Jawa siswa kelas IV salah satu SD Negeri di Boyolali masih rendah. Hal ini didukung dari hasil uji pratindakan yang menunjukkan bahwa hanya $11,11 \%$ atau 4 siswa yang mendapatkan nilaisesuai KKM dan 28 siswa atau 88,88\% memperoleh nilai di bawah KKM. $\mathrm{KKM}$ yang telah ditetapkan adalah $\geq 75$. Siklus Isiswa yang memperoleh nilai sesuai KKM ada 18 siswa atau 56,25\% dan siswa yang memperoleh nilai di bawah KKM ada 14 siswa atau $43,75 \%$ dengan nilai rata-rata 68,09 . Selanjutnya tindakan pada siklus II siswa yang memperoleh nilai sesuai $\mathrm{KKM}$ ada 28 siswaatau $87,50 \%$ dan siswa yang memperoleh nilai di bawah KKM ada 4 siswaatau 12,50 \% dengan nilai rata-rata 79,14. Hasil ketuntasan klasikal pada siklus II sebesar 87,50\%. Dari pengukuran yang dilakukan oleh Isti Khomah didapat kesimpulan bahwa penggunaan medi pop up book dapat meningkatkan ketrampilan membaca aksara Jawa pada siswa kelas IV SD Negeri I Boyolali.

Tindakan yang sama dilakukan oleh Dana Husada Rini (2018) pada siswa kelas VA SD Muhammadiyah Wonogiri. Pada kondisi awal keterampilan membaca aksara Jawa masih tergolong rendah berdasarkan uji pratindakan yang menunjukkan 5 siswa $(19,23 \%)$ dari 26 siswa yang memperoleh nilai lebih dari atau sama dengan KKM, yakni 65.Di sisi lain 21 siswa $(80,77 \%)$ mendapatkan nilai di bawah KKM. Padasiklus I nilai rata-rata kelas meningkat menjadi 68,21. Begitu juga dengan ketuntasan klasikal yang mengalami peningkatan menjadi 70,83\%. Pada siklus II nilai rata-rata kelas 81,25 dengan ketuntasan klasikal 91,67\%. 


\section{PEMBAHASAN}

Penggunaan model dan media pembelajaran dalam pembelajaran membaca dan menulis aksara jawa terbukti efektif untuk meningkatkan ketrampilan membaca dan menulis aksara Jawa. Media yang digunakan untuk meningkatkan ketrampilan menulis aksara Jawa adalah media adalah Pop Up Book. Conrado, dkk menyatakan bahwa"paper pop ups or movable books are three dimensional books that contain paper pieces that pop up out or move when the book is opened and fold completely flat when the book is closed" (2014: 2). Buku Pop Up adalah buku yang memiliki unsure tiga dimensi ketika buku tersebut dibuka dan rata kembali saat buku ditutup. Pop Up Book ini dilengkapi gambar yang dapat membuat anak lebih tertarik selama pembelajaran. Kelebihan media ini menarik karena bentuk gambar yang timbul atau berdimensi tiga, gambar yang dapat bergerak ketika buku dibuka dan gambar yang dapat diubah sesuai dengan kebutuhan materi pembelajaran. Kelebihan lain media pop up book adalah memberikan penjelasan materi secara lebih baik agar lebih mudah ditangkap oleh siswa karena media menjelaskan sistem visual (yang dapat dilihat) secara kompleks (Van Dyk, 2011: 6).

Di sisi lain, penggunaan model pembelajaran inovatif ditengarai dapat meningkatkan ketrampilan membaca aksara Jawa, terbukti dengan adanya peningkatan ketrampilan membaca setelah menggunakan model pembelajaran make a match. Kelebihan model pembelajaran make a match diantaranya adalah munculnya interaksi positif antarsiswa dalam pembelajaran. Interaksi ini sangat membantu siswa dalam menjalani proses pembelajaran yang merupakan salah satu kunci keberhasilan proses pembelajaran sebagaimana pendapat Wenger (1998) dalam Huda (2014: 49) yang menyatakan bahwa interaksi dengan orang lain dapat membantu seseorang menjadi lebih positif dalam mengikuti proses pembelajaran daripada ia menjalaninya sendiri. Dengan kata lain kondisi ini merupakan dampak penerapan model Make a Match yang sesuai dengan pernyataan Huda (2014: 253) dan juga Fidiyanti (Effect of Implementation of Cooperative Learning Model Make a Match Technique on Student Learning Motivation in Social Science Learning dalam International Journal Pedagogy of Social Studies Vol. 2, No. 1, 2017: 1-2) yang menyatakan bahwa pembelajaran yang dikemas dalam bentuk permainan akan membuat pembelajaran menjadi lebih menyenangkan sekaligus dapat meningkatkan motivasi siswa dalam belajar.

\section{KESIMPULAN}

Penggunaan model dan media pembelajaran inovatif dalam pembelajaran membaca dan menulis aksara Jawa memberikan gambaran nyata bahwa keberhasilan peningkatan ketrampilan membaca dan menulis aksara Jawa serta peningkatan kualitas proses pembelajaran dipengaruhi oleh penggunaan model dan media pembelajaran yang sesuai. Dengan kata lain dari hasil uji efektivitas dapat diketahui bahwamedia pop up book dan model pembelajaran make a match dapat diterapkan sebagai upaya untuk meningkatkan ketrampilan membaca dan menulis aksara Jawa. Di sisi lain, meningkatnya ketrampilan membaca dan menulis aksara Jawa berimplikasi pada keberhasilan upaya transfer of knowledge dari guru kepada siswa, sehingga perlu dikembangkan model danmedia pembelajaran yang inovatif sebagai upaya pelestarian terhadapeksistensiaksaraJawa di era disrupsi.

\section{DAFTAR PUSTAKA}

Cresswell, John W. 2016. Research Design: Pendekatan Metode Kualitatif, Kuantitatif, dan Campuran.Yogyakarta: Pustaka Pelajar.

Dyk, Van Stephen. 2011. Paper Engineering: Fold, Pull, Pop, and Turn. Diunduh pada 4 Desember 2017 dari http://www.sil.si.edu/pdf/FPPT_brochure.pdf.

Fidiyanti, H. H. N. (2017). Effect of Implementation of Cooperative Learning Model Make a Match Technique on Student Learning Motivation in Social Science 
Learning. International Journal Pedagogy of Social Studies Vol. 2, No. 1, 2017: 1-2. Diperoleh 12 Desember 2017 pukul 13.30 WIB.

Huda, Miftahul. (2014). Model-Model Pengajaran dan Pembelajaran. Yogyakarta: Pustaka Pelajar.

Rohmadi, Muhammad dan Lili Hartono. 2011. Kajian Bahasa, Sastra, dan Budaya Jawa Teori dan Pembelajarannya. Surakarta: Pelangi Press.

Ruiz, Conrado R, dkk. 2014. Multi-Style Paper Pop Up Designs from 3D Models. https://www.comp.nus.edu.sg/ lowkl/publications/multistyle_popup_eg2014.pd f. Diunduh 4 Desember 2017 